Check for updates

Cite this: RSC Adv., 2020, 10, 37576

Received 20th August 2020

Accepted 6th October 2020

DOI: $10.1039 / \mathrm{d} 0 \mathrm{ra0} 07172 \mathrm{~b}$

rsc.li/rsc-advances

\title{
A molten salt-based nitridation approach for synthesizing nanostructured InN electrode materials $\uparrow$
}

\begin{abstract}
Gani Purwiandono, ${ }^{\text {ab }}$ Kazuhiro Manseki (D) ${ }^{* a}$ and Takashi Sugiura ${ }^{a}$
Single-phase $\mathrm{InN}$ nanocrystals were synthesized for the first time by a molten salt-based nitridation approach using $\mathrm{InCl}_{3}$ and $\mathrm{LiNH}_{2}$ as indium and nitrogen sources, respectively. A molten salt, $\mathrm{KCl}-\mathrm{LiCl}$, during nitridation, enabled us to obtain $\mathrm{InN}$ nanocrystals at relatively low temperatures ranging from $400{ }^{\circ} \mathrm{C}$ to $500{ }^{\circ} \mathrm{C}$. SEM and HR-TEM measurements coupled with XRD data revealed that $\mathrm{InN}$ nanocrystals were formed with average grain sizes of approximately 50-60 nm. Notably, the photoelectrochemical cell fabricated using the $\operatorname{lnN}$ nanocrystals synthesized at $450{ }^{\circ} \mathrm{C}$ exhibited a photocurrent response under light irradiation from $400 \mathrm{~nm}$ to $880 \mathrm{~nm}$. The precise control of the growth of $\mathrm{InN}$ particles using our synthetic approach provides opportunities for developing versatile nitride nanocrystals
\end{abstract}

\section{Introduction}

Indium nitride ( $\mathrm{InN}$ ) has been regarded as an attractive semiconductor for device applications such as light-emitting diodes (LEDs) and infrared detectors. ${ }^{1-5}$ Moreover, the narrow band gap, typically from $0.6 \mathrm{eV}$ to $0.9 \mathrm{eV}$, enables the detection of its spectral range in the near-infrared region. ${ }^{6-13}$ In growing pure InN, the main difficulty lies in its thermal decomposition, which becomes significant above $600{ }^{\circ} \mathrm{C}$. In addition, hightemperature treatment causes the inclusion of impurities, especially oxygen atoms..$^{14,15}$

Much attention has been given to the synthesis of singlephase InN using several methods, such as molecular beam epitaxy (MBE), metal organic chemical vapor deposition (MOCVD), and plasma and sputtering techniques. ${ }^{16-23}$ However, few reports are available on nitridation reactions for growing nanoscale InN crystals.

Jung et $a l .{ }^{24}$ reported the gas-phase nitridation synthesis of InN with $\mathrm{NH}_{3}$ gas at $600{ }^{\circ} \mathrm{C}$. InN particles with a diameter of approximately $300 \mathrm{~nm}$ were obtained. Our group has previously demonstrated the formation of $\mathrm{InN}$ at $400{ }^{\circ} \mathrm{C}$ using $\operatorname{In}_{2} \mathrm{O}_{3}$ as an indium source in indium flux under $\mathrm{N}_{2}$ gas flow. Particulate InN crystals with a diameter of approximately $800 \mathrm{~nm}$ were obtained. ${ }^{25}$ These studies have demonstrated the effect of raw materials $\left(\mathrm{In}_{2} \mathrm{O}_{3}\right.$ and $\left.\mathrm{LiNH}_{2}\right)$ on the morphology of InN crystals. However, none of the above-mentioned studies have

${ }^{a}$ The Graduate School of Natural Science and Technology, Gifu University, 501-1193, Japan.E-mail: kmanseki@gifu-u.ac.jp

${ }^{b}$ Department of Chemistry, Universitas Islam Indonesia, 55584, Indonesia

$\dagger$ Electronic supplementary information (ESI) available. See DOI: $10.1039 /$ dora07172b investigated the morphology control of InN particles at the nanoscale and their photoelectrochemical properties.

We have successfully synthesized 2D hexagonal-shaped GaN nanoplates through the reaction of $\mathrm{GaCl}_{3}$ and $\mathrm{LiNH}_{2}$ using $\mathrm{LiCl}$ as the molten salt. ${ }^{26}$ The use of $\mathrm{LiCl}$ as the molten salt was found to accelerate the homogenous GaN formation at the nanoscale. Photoelectrochemical analysis of the GaN electrode revealed that the hexagonal-shaped GaN electrode exhibited an anodic photocurrent that was higher by a factor of 2 compared to that of the random-shaped GaN. With regards to the InN photoelectrode, Lindgren et al. ${ }^{27}$ reported an incident photon-toelectron conversion efficiency (IPCE) of InN film of up to $2 \%$ at $350 \mathrm{~nm}$, whereas no photocurrent response was observed in the visible and near-IR regions.

The particular importance of our molten salt-based synthesis lies in the size control of InN particles at a nanoscale, which is a new concept for synthesizing InN nanocrystals. Our previous study on LiCl-based GaN synthesis showed that the $\mathrm{Cl}^{-}$anions of LiCl can suppress the crystal growth of $\mathrm{GaN}$ through the $\mathrm{Cl}^{-}$ coordination to $\mathrm{Ga}(\mathrm{III}) .{ }^{26}$ Based on the results, we anticipated that InN nanocrystals could be synthesized using LiClcontaining molten salts. In this paper, we use a $\mathrm{KCl}-\mathrm{LiCl}$ mixture with eutectic composition of $60 \% \mathrm{~mol} \mathrm{LiCl}$ and $40 \% \mathrm{~mol} \mathrm{KCl}$ that has a melting point of $353{ }^{\circ} \mathrm{C}$ (as shown in Table $\mathrm{S} 1 \uparrow^{28}$ ), taking into consideration that the molten salts for nitridation reactions of InN should have a melting point that is lower than the synthesis temperature at $400-500{ }^{\circ} \mathrm{C} . .^{25,29}$

Herein, we present, for the first time, the effect of molten salt on the nitridation synthesis of single-phase InN nanocrystals. The InN nanocrystals were successfully obtained at relatively low temperatures ranging from $400{ }^{\circ} \mathrm{C}$ to $500{ }^{\circ} \mathrm{C}$. In addition, the photoelectrochemical cell fabricated using the InN 
electrodes exhibited a photocurrent response under visible and near-IR light irradiation. Importantly, our methodology for controlling the growth of InN nanocrystals using molten saltassisted nitridation provides a new approach to create various nitride nanocrystals and their electrodes for photo-energy conversion.

\section{Experimental section}

\section{Synthesis of InN nanocrystals}

$\mathrm{InCl}_{3}(0.664 \mathrm{~g}, 1 \mathrm{~mol}), \mathrm{LiNH}_{2}(0.482 \mathrm{~g}, 7 \mathrm{~mol}), \mathrm{LiCl}(0.153 \mathrm{~g}, 0.8$ $\mathrm{mol})$, and $\mathrm{KCl}(0.179 \mathrm{~g}, 1.2 \mathrm{~mol})$ were mixed in a graphite crucible (inner diameter: $55 \mathrm{~mm}$, length: $309 \mathrm{~mm}$, SUS 316) under $\mathrm{N}_{2}$ atmosphere $\left(50 \mathrm{~mL} \mathrm{~min}^{-1}\right)$. The mixture was preheated at $150{ }^{\circ} \mathrm{C}$ for $30 \mathrm{~min}$. The nitridation reactions were then carried out at $350{ }^{\circ} \mathrm{C}, 400{ }^{\circ} \mathrm{C}, 450{ }^{\circ} \mathrm{C}, 500{ }^{\circ} \mathrm{C}$, and $550{ }^{\circ} \mathrm{C}$ for $2 \mathrm{~h}$ under $\mathrm{N}_{2}$ atmosphere. The ramping rate for the nitridation reaction was set to $10{ }^{\circ} \mathrm{C} \mathrm{min}{ }^{-1}$, and the cooling rate was set to $2{ }^{\circ} \mathrm{C} \mathrm{min}{ }^{-1}$. After cooling, the products were washed with $1 \mathrm{M}$ $\mathrm{HCl}$ and ethanol to obtain InN powder samples.

\section{Preparation of InN photoelectrodes}

InN/titanium paste electrodes were prepared to examine the photoelectrochemical properties of InN films with a thickness of 0.5 $\mu \mathrm{m}$. To prepare InN electrodes, the as-synthesized InN powder was mixed with a 2-butanol solution (20 wt $\%$, Wako, $99 \%$ ) for $24 \mathrm{~h}$. The paste was deposited on a Ti substrate (Nilaco) by the doctor blade technique using scotch tape as a spacer. Prior to deposition, the Ti substrate was cleaned with an etching solution (a mixture of $7 \mathrm{~mL}$ distilled water, $5 \mathrm{~mL} \mathrm{HNO}_{3}$ (Nacalai Tesque, 60\%), and $1 \mathrm{~mL} \mathrm{HF}$ (Wako, 46\%)). The heat treatment was performed at $350{ }^{\circ} \mathrm{C}$ for $2 \mathrm{~h}$ under a $\mathrm{N}_{2}$ atmosphere. Then, $5 \mathrm{~mL}$ of a $\mathrm{NaOH}(5 \mathrm{mM}$, Kanto, $97 \%)$ solution was added to $20 \mathrm{~mL}$ of a $\mathrm{Co}\left(\mathrm{NO}_{3}\right)_{2} \cdot 6 \mathrm{H}_{2} \mathrm{O}(5 \mathrm{mM}$, Wako, 99.5\%) solution, and a portion of this mixture was dropped onto the InN film. Subsequently, heat treatment was performed at $350{ }^{\circ} \mathrm{C}$ for $2 \mathrm{~h}$ under a $\mathrm{N}_{2}$ atmosphere.

\section{Structural characterization of InN powder}

The structure of the InN powder was analyzed by X-ray diffraction (XRD, Rigaku Ultima II/OC) with $\mathrm{CuK}_{\alpha}$ radiation and transmission electron microscopy (TEM, JEOL, JEM-2100). The morphology of the InN particles was observed by scanning electron microscopy (SEM, Hitachi, S-4800). The elemental analysis of the samples was performed via X-ray photoelectron spectroscopy (XPS, ULVAC, Quantera SXM). The specific surface areas of the InN powders were determined using a gas sorption analyzer (Micromeritics Tristar II 3020). The absorbance measurements were carried out on a UV-vis spectrophotometer (Hitachi, U-4000).

The Debye-Scherrer equation was applied to determine the crystallite size of InN powder using eqn (1). $D, \lambda, \beta$ and $\theta$ correspond to the crystallite size, wavelength of X-ray radiation, full width at half maximum (FWHM), and diffraction angle, respectively.

$$
D=\frac{0.94 \lambda}{\beta} \cos \theta
$$

\section{Photoelectrochemical measurements}

Photoelectrochemical measurements were performed with a three-electrode cell consisting of the InN photoanode, saturated calomel reference electrode, and platinum counter electrode using $1 \quad \mathrm{M}^{2} \mathrm{Na}_{2} \mathrm{SO}_{4} \quad\left(\begin{array}{llllll}50 & \mathrm{~mL}\end{array}\right) . \quad \mathrm{H}_{2} \mathrm{O}_{2} \quad\left(\begin{array}{llll}1 & \mathrm{~mL}, & 30 \%\end{array}\right.$ concentration) was also added to the electrolyte. ${ }^{28,30}$ The current-voltage characteristics were obtained using a potentiostat under intermittent UV light irradiation with a light intensity

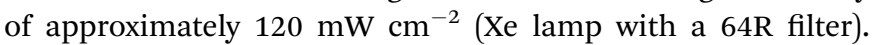
Mott-Schottky analysis was applied to determine the donor density $\left(N_{\mathrm{D}}\right)$ of the InN electrodes using eqn (2). $E, E_{\mathrm{FB}}$, and $c$ correspond to the applied potential, flat band potential, and space charge capacitance in the electrode, respectively. $T, k, e$, $\varepsilon_{\mathrm{o}}$, and $\varepsilon$ are the absolute temperature, Boltzmann constant, elemental charge, vacuum permittivity, and relative permittivity, respectively. A relative permittivity of $15.3 \mathrm{~F} \mathrm{~m}^{-1}$ was used to obtain the $N_{\mathrm{D}}$ value using eqn (3). The Mott-Schottky plots were obtained using a VersaSTAT3 potentiostat. The measurements were performed using a $1 \mathrm{M} \mathrm{Na}_{2} \mathrm{SO}_{4}$ solution at a given bias potential under dark conditions. The measured frequency was $1 \mathrm{kHz}$.

$$
\begin{gathered}
\frac{1}{c^{2}}=\left(E-E_{\mathrm{FB}}-k T / e\right) / N_{\mathrm{D}} e \varepsilon_{\mathrm{o}} \varepsilon \\
N_{\mathrm{D}}=\frac{2\left(\frac{\mathrm{d} E}{\mathrm{~d}}\right) / \mathrm{d}\left(\frac{1}{c^{2}}\right)}{e \varepsilon_{\mathrm{o}} \varepsilon}
\end{gathered}
$$

The IPCE measurements were performed using a threeelectrode configuration with an InN working electrode, a Ag/ $\mathrm{AgCl}$ reference electrode, and a platinum counter electrode. The electrodes were immersed in the same electrolyte as mentioned above. The quantum efficiency was recorded at an applied potential of $1.0 \mathrm{~V} v$ s. Ag/AgCl. A metal halide lamp was used with bandpass cut filters (400, 450, 500, 550, 600, 650, 700, and $880 \mathrm{~nm})$. The incident light intensities were $3.0-8.0 \mathrm{~mW}$ $\mathrm{cm}^{-2}$ for each filter to obtain the IPCE using eqn (4).

$$
\begin{aligned}
& \operatorname{IPCE}(\%)= \\
& \frac{1240 \times \text { photocurrent density }\left(\mu \mathrm{A} \mathrm{cm}^{-2}\right)}{\text { incident light wavelength }(\mathrm{nm}) \times \text { light intensity }\left(\mathrm{mW} \mathrm{cm}^{-2}\right)}
\end{aligned}
$$

\section{Results and discussion}

\section{Synthesis of InN nanocrystals}

Fig. 1 shows the XRD pattern of the synthesized InN powders using $\mathrm{LiCl}-\mathrm{KCl}$ as the molten salt at various temperatures. The diffraction peaks of the InN products can be indexed to the JCPDS data (PDF: 79-2498). At temperatures of $400{ }^{\circ} \mathrm{C}, 450{ }^{\circ} \mathrm{C}$, and $500{ }^{\circ} \mathrm{C}$, no peaks of byproducts were detected, indicating the formation of single-phase InN crystals for all samples. A control reaction at $350{ }^{\circ} \mathrm{C}$, which is lower than the melting point of LiCl-KCl $\left(353{ }^{\circ} \mathrm{C}\right)$, was also carried out. Peaks of InN and $\mathrm{InCl}_{3}$ were observed as byproducts, suggesting that LiCl- 


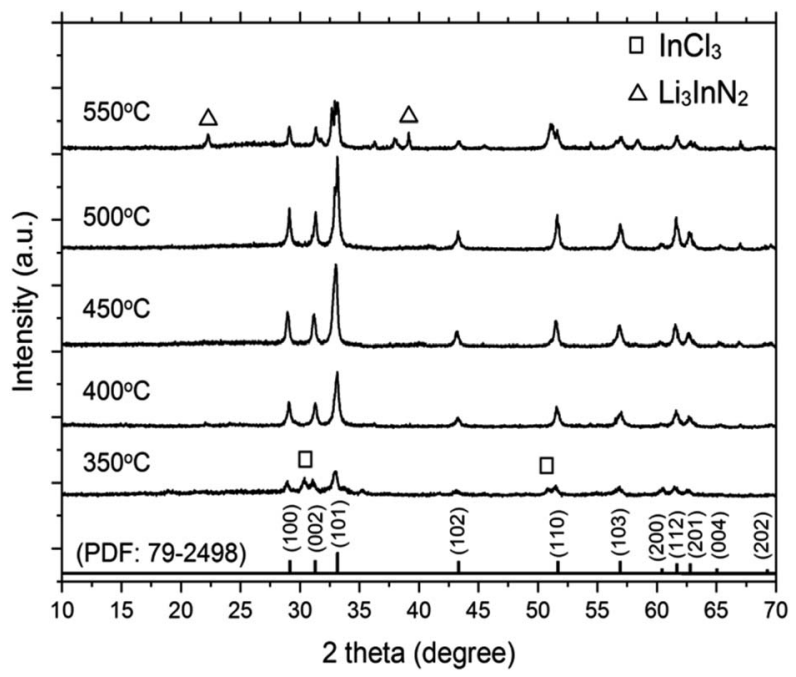

Fig. 1 XRD patterns of InN synthesized using $\operatorname{lnCl} l_{3}, \mathrm{LiNH}_{2}$, and $\mathrm{LiCl}-$ $\mathrm{KCl}$. The reactions were carried out at $350^{\circ} \mathrm{C}, 400^{\circ} \mathrm{C}, 450^{\circ} \mathrm{C}, 500^{\circ} \mathrm{C}$, and $550{ }^{\circ} \mathrm{C}$.

$\mathrm{KCl}$ could act as a reactant at temperatures below the melting point. Furthermore, at higher reaction temperatures $\left(400{ }^{\circ} \mathrm{C}\right.$ and $450{ }^{\circ} \mathrm{C}$ ), the intensity of all the InN diffraction peaks increased when compared to that at $350{ }^{\circ} \mathrm{C}$. These observations indicate that $\mathrm{LiCl}-\mathrm{KCl}$ plays a crucial role in facilitating the single-phase crystal growth of InN. However, this trend was only observed up to $500{ }^{\circ} \mathrm{C}$. Above $550{ }^{\circ} \mathrm{C}$, the peak corresponding to the (101) plane significantly decreased, and $\mathrm{Li}_{3} \mathrm{InN}_{2}$ was concomitantly formed. This result was probably due to the decomposition of InN. The crystallite sizes along the (101) plane of InN are presented in Table 1. The largest crystallite size of $53 \mathrm{~nm}$ was obtained from the sample prepared at $450{ }^{\circ} \mathrm{C}$.

To characterize the product, XPS spectra were obtained (Fig. S1 $\dagger$ ). For the reaction temperatures of $400{ }^{\circ} \mathrm{C}, 450{ }^{\circ} \mathrm{C}$, and $500^{\circ} \mathrm{C}$, the binding energies of In $3 \mathrm{~d}_{5 / 2}$ and $\mathrm{N} 1 \mathrm{~s}$ were 443.6 and $396.5 \mathrm{eV}$, respectively. The binding energies of In $3 \mathrm{~d}_{5 / 2}$ and $\mathrm{N} 1 \mathrm{~s}$ were consistent with the reported values for InN, and no peaks corresponding to $\mathrm{Cl} 2 \mathrm{p}$ and $\mathrm{Li} 1 \mathrm{~s}$ originating from byproducts were observed. ${ }^{29,31}$ For samples prepared at $350{ }^{\circ} \mathrm{C}$ and $550{ }^{\circ} \mathrm{C}$, peaks at $57.5 \mathrm{eV}$ and $198.9 \mathrm{eV}$ corresponding to $\mathrm{Li} 1 \mathrm{~s}$ and $\mathrm{Cl} 2 \mathrm{p}$, respectively, were detected.

Table 1 Reaction yields and structure characterization of $\ln N$ nanocrystals

\begin{tabular}{|c|c|c|c|c|}
\hline $\begin{array}{l}\text { InN } \\
\text { sample }\end{array}$ & $\begin{array}{l}\text { Reaction } \\
\text { yields } \\
(\%)\end{array}$ & $\begin{array}{l}\text { Specific } \\
\text { surface area } \\
\left(\mathrm{m}^{2} \mathrm{~g}^{-1}\right)\end{array}$ & $\begin{array}{l}\text { Average } \\
\text { grain size } \\
(\mathrm{nm})\end{array}$ & $\begin{array}{l}\text { Crystallite } \\
\text { size }^{a} \\
(\mathrm{~nm})\end{array}$ \\
\hline $400{ }^{\circ} \mathrm{C}$ & 42 & 13 & 49 & 41 \\
\hline $450{ }^{\circ} \mathrm{C}$ & 72 & 12 & 59 & 53 \\
\hline $500{ }^{\circ} \mathrm{C}$ & 62 & 14 & 51 & 50 \\
\hline
\end{tabular}

${ }^{a}$ Determined using the XRD data of InN corresponding to the (101) plane.
SEM images of InN powder samples formed at 350, 400, 450, 500 , and $550{ }^{\circ} \mathrm{C}$ are shown in Fig. 2a and S2. $\dagger$ The SEM images clearly indicated that with the use of $\mathrm{LiCl}-\mathrm{KCl}$ as the molten salt, InN nanocrystals with grain sizes smaller than $100 \mathrm{~nm}$ were formed at $400{ }^{\circ} \mathrm{C}, 450{ }^{\circ} \mathrm{C}$, and $500{ }^{\circ} \mathrm{C}$ (Table 1). The largest grain size was $59 \mathrm{~nm}$, which was measured for the sampled prepared at $450{ }^{\circ} \mathrm{C}$. The BET specific surface areas of these three samples had comparable values of approximately $12-14 \mathrm{~m}^{2} \mathrm{~g}^{-1}$, as summarized in Fig. S3. $\dagger$

The reaction yields and crystallite sizes for the (101) plane of InN synthesized at different temperatures are also shown in Table 1 . The crystallite sizes along the (101) plane of InN synthesized at 400,450 , and $500{ }^{\circ} \mathrm{C}$ were $41 \mathrm{~nm}, 53 \mathrm{~nm}$, and $50 \mathrm{~nm}$, respectively. The reaction yields increased with increasing reaction temperature from $400{ }^{\circ} \mathrm{C}$ to $450{ }^{\circ} \mathrm{C}$. The highest reaction yield $(72 \%)$ for the (101) plane was calculated for InN synthesized at $450{ }^{\circ} \mathrm{C}$.

To understand the role of molten salt in crystal growth, we synthesized InN without LiCl-KCl (the XRD pattern and SEM images are presented in Fig. S4 and S5 $\dagger$ ). In contrast to that of the molten salt synthesis, the XRD pattern exhibited peaks that
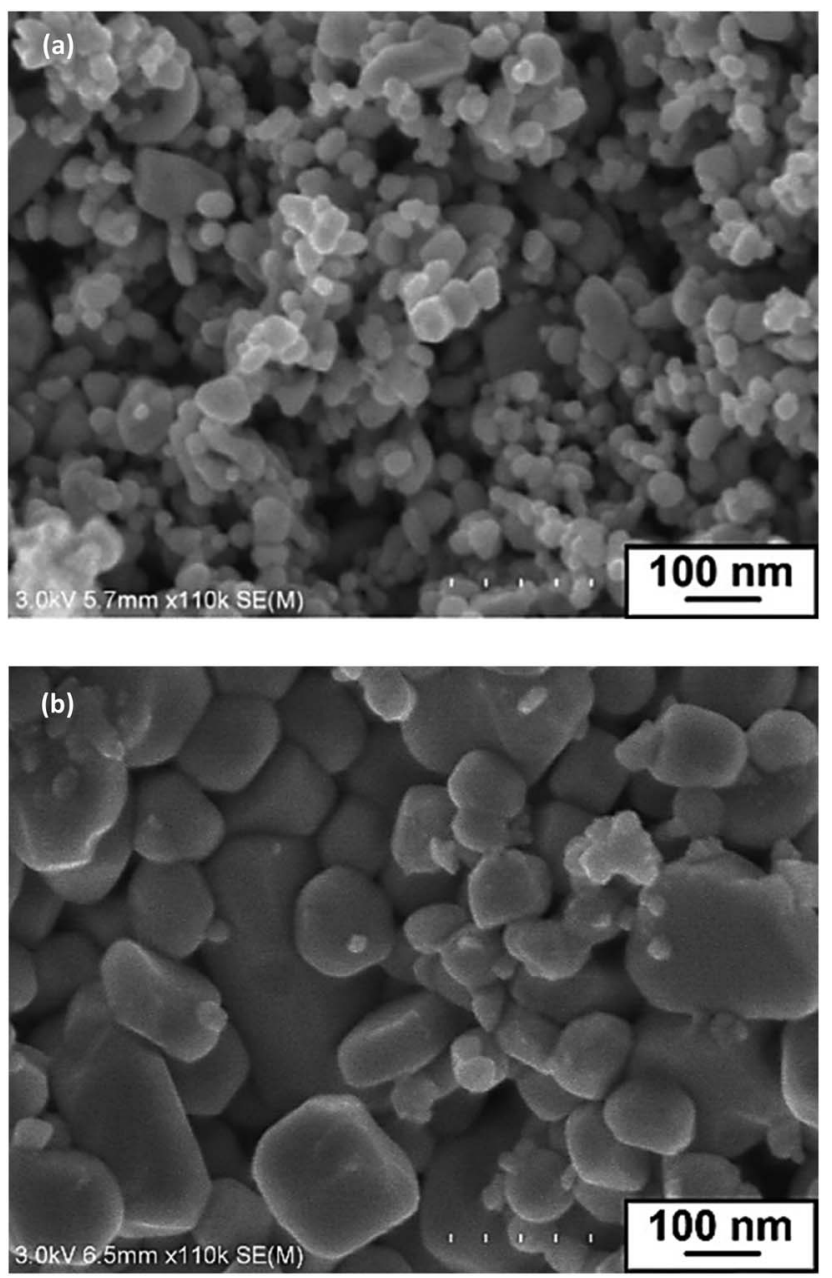

Fig. 2 SEM images of $\operatorname{InN}$ samples prepared at $450{ }^{\circ} \mathrm{C}$ by the reaction of (a) $\mathrm{InCl}_{3}, \mathrm{LiNH}_{2}$ and $\mathrm{LiCl}-\mathrm{KCl}$ and (b) $\mathrm{InCl}_{3}$ and $\mathrm{LiNH}_{2}$. 


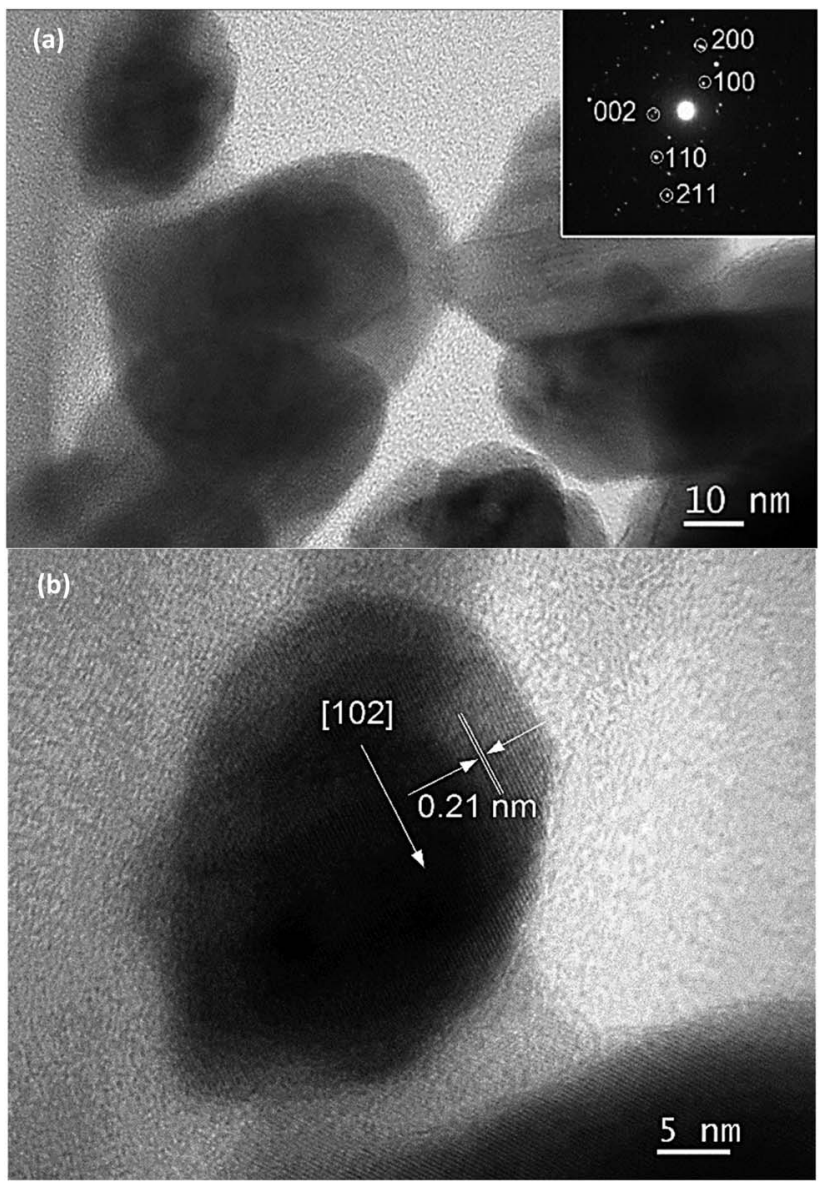

Fig. 3 TEM images of (a) $\operatorname{lnN}$ nanocrystals synthesized at $450{ }^{\circ} \mathrm{C}$ for $2 \mathrm{~h}$ and (b) lattice fringe of (100) plane.

were assigned to the byproduct InLi (Fig. S4†). The SEM images indicated that the average grain size of InN synthesized without molten salt was significantly larger than that obtained using the molten salt (Fig. S5 $\dagger$ ); Fig. 2b shows one of such SEM images (450 ${ }^{\circ} \mathrm{C}$ sample). Considering that a random-shaped morphology with an average grain size of $200 \mathrm{~nm}$ was obtained, it is likely that the LiCl-KCl molten salt contributed to the suppression of InN growth, leading to the size reduction in the InN formation.

The high resolution transmission electron microscope (HRTEM) images of InN nanocrystals synthesized at $450{ }^{\circ} \mathrm{C}$ are also presented in Fig. 3a. A lattice fringe of $0.30 \mathrm{~nm}$ corresponding to the spacing of the (100) plane was observed (Fig. 3b). Analysis of the selected area electron diffraction (SAD) pattern indicated that single-phase InN nanocrystals were present.

The plausible reactions for the formation of InN nanocrystals are shown below.

$$
\begin{gathered}
2 \mathrm{InCl}_{3}+6 \mathrm{LiNH}_{2} \rightarrow 2 \mathrm{Li}_{3} \mathrm{InN}_{2}+3 \mathrm{Cl}_{2}+6 \mathrm{H}_{2}+\mathrm{N}_{2} \\
2 \mathrm{Li}_{3} \mathrm{InN}_{2}+3 \mathrm{Cl}_{2} \rightarrow 2 \mathrm{InN}+6 \mathrm{LiCl}+\mathrm{N}_{2}
\end{gathered}
$$

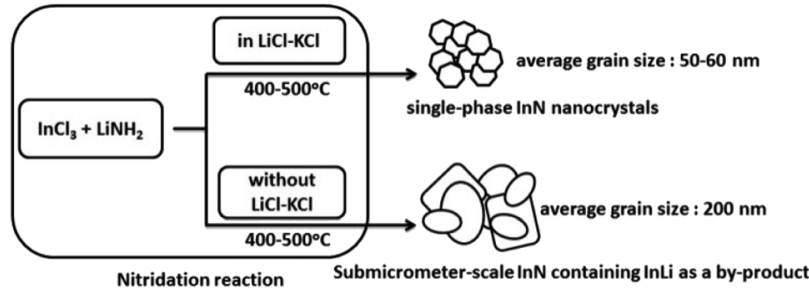

Fig. 4 Schematic diagram of the effect of molten salt on the crystal growth of $\ln N$

In the first step (eqn (5)), the mixture of reactants $\left(\mathrm{InCl}_{3}\right.$ and $\mathrm{LiNH}_{2}$ ) and the LiCl-KCl salt were uniformly heated, resulting in the decomposition of $\mathrm{LiNH}_{2}$ at $370{ }^{\circ} \mathrm{C}$ to form $\mathrm{Li}_{3} \mathrm{InN}_{2}$ particles. It is presumed that the InN nanocrystals were formed by the decomposition of $\mathrm{Li}_{3} \mathrm{InN}_{2}$ in the second step (eqn (6)). Single-phase InN without any byproduct was observed at temperatures from $400{ }^{\circ} \mathrm{C}$ to $500{ }^{\circ} \mathrm{C}$. Upon increasing the reaction temperature to $550{ }^{\circ} \mathrm{C}, \mathrm{Li}_{3} \mathrm{InN}_{2}$ was produced as a byproduct, as shown in the XRD pattern. The decreased intensity of InN indicated that InN started to decompose at approximately $550{ }^{\circ} \mathrm{C}$.

In a previous study, we successfully synthesized GaN nanoplates using $\mathrm{LiCl}$ as the molten salt. The molten salt could accelerate the homogenous formation at the nanoscale during the nucleation and crystal growth of GaN particles. ${ }^{26}$ The effect of LiCl-KCl on the crystal growth of InN can be explained as follows (Fig. 4): excess $\mathrm{Cl}^{-}$anions in the nitridation process (eqn (6)) can interact with the (100), (002), and (101) surfaces. This phenomenon probably leads to the suppression of crystal growth, producing InN nanocrystals with a narrow size distribution. However, without the use of LiCl-KCl as the molten salt, it is likely that the lack of $\mathrm{Cl}^{-}$anions resulted in the formation of random-shaped particles.

A few solid-state nitridation reactions have been reported to promote the formation of InN. One reported reaction condition includes the use of $\mathrm{NaNH}_{2}$ as a solid-nitrogen source for $\mathrm{LinO}_{2}$; InN aggregates with a size range of 50-300 nm were synthesized at $240{ }^{\circ} \mathrm{C} .{ }^{30,32}$ Most importantly, our nitridation using a moltensalt is unique in that the reaction allowed us to form $\mathrm{InN}$ with a narrow size distribution, as shown in Fig. 2a.

In order to determine the band gap, the absorption spectra of InN thin films were also measured from 300 to $2500 \mathrm{~nm}$, as shown in Fig. S6. $\uparrow$ The band gaps of InN synthesized at 400, 450, and $500{ }^{\circ} \mathrm{C}$ were estimated to be $0.8-0.9 \mathrm{eV}$, which is consistent with the reported value for InN. ${ }^{\mathbf{1 1 - 1 3}}$

As mentioned above, we have previously synthesized GaN nanoplates through the reaction of $\mathrm{GaCl}_{3}$ and $\mathrm{LiNH}_{2}$ using $\mathrm{LiCl}$ under $\mathrm{N}_{2}$ atmosphere. ${ }^{26}$ In addition, Carter et al. ${ }^{33}$ have reported the nitridation reaction of aluminum nitride (AlN) from $\mathrm{AlCl}_{3}$ in trimethylphenylammonium chloride (TMPAC) as a molten salt under $\mathrm{NH}_{3}$ gas. The polycrystalline AlN was successfully synthesized at $900{ }^{\circ} \mathrm{C}$. Our synthetic protocol using a molten salt approach could have significant potential for synthesizing various metal nitride nanocrystals from a metal chloride. 


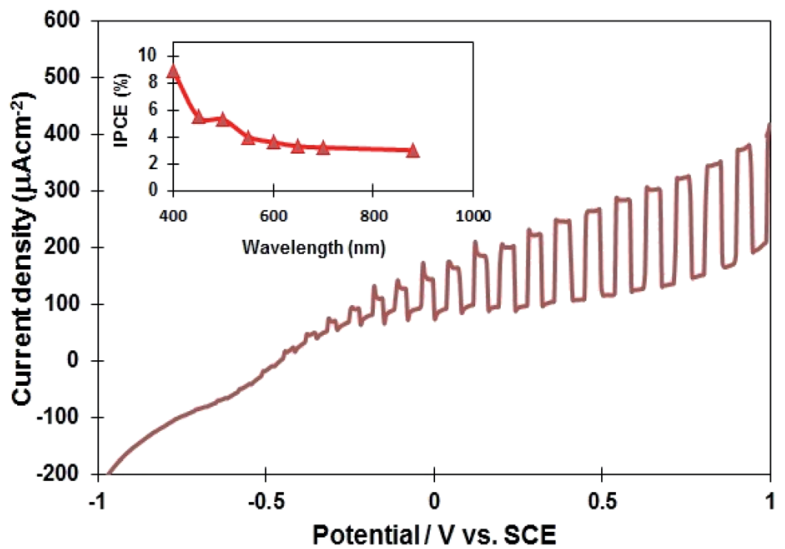

Fig. 5 A current potential curve of the InN electrode under Xe lamp illumination (the $\ln \mathrm{N}$ sample synthesized at $450{ }^{\circ} \mathrm{C}$ ). The inset shows IPCE as a function of wavelength for the $\operatorname{InN}$ electrode.

Table 2 The photoelectrochemical properties of $\ln N$ nanocrystals

\begin{tabular}{|c|c|c|c|}
\hline $\begin{array}{l}\text { InN } \\
\text { sample }\end{array}$ & $\begin{array}{l}\text { Onset } \\
\text { potential } \\
V_{\text {on }}(\mathrm{V} v s . \mathrm{SCE})\end{array}$ & $\begin{array}{l}\text { Photocurrent density } \\
\left(\mu \mathrm{A} \mathrm{cm}^{-2}\right) \\
(\text { at } 1.0 \mathrm{~V})\end{array}$ & $\begin{array}{l}\text { Donor } \\
\text { density }\left(N_{\mathrm{D}}\right) \\
\left(10^{20} \mathrm{~cm}\right)\end{array}$ \\
\hline $400{ }^{\circ} \mathrm{C}$ & -0.75 & 361.8 & 7.86 \\
\hline $450^{\circ} \mathrm{C}$ & -0.72 & 406.0 & 5.62 \\
\hline $500{ }^{\circ} \mathrm{C}$ & -0.71 & 380.8 & 7.89 \\
\hline
\end{tabular}

\section{Photoelectrochemical properties of InN nanocrystals}

Several InN electrodes synthesized at $400{ }^{\circ} \mathrm{C}, 450^{\circ} \mathrm{C}$, and $500{ }^{\circ} \mathrm{C}$ were prepared to examine their photoelectrochemical properties. The current-potential curve of the InN electrode synthesized at $450{ }^{\circ} \mathrm{C}$ is presented in Fig. 5 (the curves for the $400{ }^{\circ} \mathrm{C}$ and $500^{\circ} \mathrm{C}$ samples are shown in Fig. S7 $\dagger$ ). The results indicated that all the InN electrodes contained n-type semiconductors. Typically, the onset potential of the InN sample synthesized at $450{ }^{\circ} \mathrm{C}$ was found to be $-0.72 \mathrm{~V} v s$. SCE, and the photocurrent density at $1.0 \mathrm{~V}$ was $406 \mu \mathrm{A} \mathrm{cm}{ }^{-2}$, which was found to be the highest among the three samples (Table 2). InN is normally doped with oxygen impurities, which make it n-type. Therefore, the photoresponse observed for all samples was thought to originate from the InN electrodes.

To understand the carrier transport of InN electrodes, we compared the donor density of the InN samples using MottSchottky plots (Fig. S8 $\dagger$ ). As summarized in Table 2, InN samples synthesized at $450{ }^{\circ} \mathrm{C}$ had the lowest donor density, which probably led to the improvement of the photocurrent in the InN electrode.

The inset in Fig. 5 displays the quantum efficiency of the InN electrode synthesized at $450{ }^{\circ} \mathrm{C}$. The photoelectrochemical cell consisting of the InN nanocrystals exhibited an IPCE response in the visible and near-IR region (400-880 nm). The IPCE was estimated to be $9 \%$ at $400 \mathrm{~nm}$ and $3.6 \%$ at $880 \mathrm{~nm}$. Lindgren et al. ${ }^{27}$ reported that the maximum IPCE of InN thin film electrodes was $2 \%$ at $350 \mathrm{~nm}$, whereas no photoresponse was observed in the visible region. It is worth noting that responses in the visible and near-IR regions were observed for the first time using our nanostructured InN electrode material. In addition, we have compared the photocurrent of InN electrodes using a reported data. ${ }^{27}$ For our experiments (Table 2), the observed photocurrents for the InN electrodes synthesized at $400{ }^{\circ} \mathrm{C}, 450{ }^{\circ} \mathrm{C}$, and $500{ }^{\circ} \mathrm{C}$ were $297.1 \mu \mathrm{A} \mathrm{cm}^{-2}, 323.9 \mu \mathrm{A} \mathrm{cm}{ }^{-2}$, and $297.1 \mu \mathrm{A} \mathrm{cm}^{-2}$ at $0.7 \mathrm{~V}$, respectively. Lindgren et al. ${ }^{27}$ reported the DC magnetron reactive sputtered method to obtain an InN thin-film electrode at $425^{\circ} \mathrm{C}$. Agglomerated InN nanocrystals consisted of two phases of $\mathrm{InN}$ and $\mathrm{In}_{2} \mathrm{O}_{3}$ formed during annealing process. The photocurrent of InN electrode was $33 \mu \mathrm{A}$ $\mathrm{cm}^{-2}$ at $0.7 \mathrm{~V}$ under Xe lamp irradiation, which was much lower than those of our InN electrodes. Our nitridation-based molten salt may provide a single-phase InN, leading to the higher photocurrent density.

\section{Conclusions}

For the first time, we synthesized single-phase InN nanocrystals through the reaction of $\mathrm{InCl}_{3}$ and $\mathrm{LiNH}_{2}$ using $\mathrm{LiCl}-\mathrm{KCl}$ as the molten salt. The InN nanocrystals were successfully obtained at relatively low temperatures ranging from $400{ }^{\circ} \mathrm{C}$ to $500{ }^{\circ} \mathrm{C}$. The use of a molten salt could accelerate the homogeneous formation of InN nanocrystals with sizes of 50-60 nm. Notably, the photoelectrochemical cell fabricated using the InN nanocrystals exhibited an IPCE response in the visible and near-IR region (400-880 nm). The precise control of the growth of InN nanocrystals using molten salt-assisted nitridation will shed light on a new generalized approach to create versatile nitride nanocrystals.

\section{Conflicts of interest}

There are no conflicts to declare.

\section{References}

1 S. K. O'Leary, B. E. Foutz, M. S. Shur, U. V. Bhapkar and L. F. Eastman, J. Appl. Phys., 1998, 83(2), 826-829.

2 B. E. Foutz, S. K. O'Leary, M. S. Shur and L. F. Eastman, J. Appl. Phys., 1999, 85(11), 7727-7734.

3 V. M. Polyakov and F. Schwierz, Appl. Phys. Lett., 2006, 88(3), 032101.

4 M. T. Hasan, M. J. Islam, R.-U. Hasan, M. S. Islam, S. Yeasmin, A. G. Bhuiyan, M. R. Islam and A. Yamamoto, Phys. Status Solidi C, 2010, 7, 1825.

5 M. M. Hossain, M. A. Humayun, M. T. Hasan, A. G. Bhuiyan, A. Hashimoto and A. Yamamoto, IEICE T. Electron, 2012, E95C, 255.

6 Y. Zhao, H. Wang, G. Wu, Q. Jing, H. Yang, F. Gao, W. Li, B. Zhang and G. Du, J. Lumin., 2016, 173, 1-4.

7 T. Burak, S. Alkis, M. Alevli, N. Dietz, B. Ortaç, N. Biyikli and A. K. Okyay, IEEE Electron Device Lett., 2014, 35(9), 936-938.

8 J. Wu, W. Walukiewicz, W. Shan, K. M. Yu, J. W. Ager III, S. X. Li, E. E. Haller, H. Lu and W. J. Schaff, J. Appl. Phys., 2003, 94(7), 4457-4460. 
9 P. Carrier and S. H. Wei, AIP Conf. Proc., 2005, 772(1), 287288.

10 E. Kurimoto, M. Hangyo, H. Harima, M. Yoshimoto, T. Yamaguchi, T. Araki, Y. Nanishi and K. Kisoda, Appl. Phys. Lett., 2004, 84(2), 212-214.

11 Q. X. Guo, T. Tanaka, M. Nishio, H. Ogawa, X. D. Pu and W. Z. Shen, Appl. Phys. Lett., 2005, 23, 231913.

12 V. Davydov, A. A. Yu, R. P. Klochikhin, V. V. Seisyan, S. V. Emtsev, F. Ivanov, J. Bechstedt, J. Furthmüller, H. Harima, A. V. Mudryi, J. Aderhold and O. Semchinova, Phys. Status Solidi B, 2002, 229(3), r1-r3.

13 E. Kurimoto, M. Hangyo, H. Harima, M. Yoshimoto, T. Yamaguchi, T. Araki, Y. Nanishi and K. Kisoda, Appl. Phys. Lett., 2004, 84(2), 212-214.

14 H. Masataka and T. Matsui, J. Cryst. Growth, 2003, 252(1-3), 128-135.

15 W. Xinqiang and A. Yoshikawa, Prog. Cryst. Growth Charact., 2004, 48-49, 42-103.

16 Z. Bi, J. Cryst. Growth, 2007, 300, 123-126.

17 J. B. Wang, Z. F. Li, P. P. Chen, W. Lu and T. Yao, Acta Mater., 2007, 55, 183-187.

$18 \mathrm{~J}$. Wu, W. Walukiewica, W. Shan, K. M. Yu and J. W. Ager, J. Appl. Phys., 2003, 94, 4457-4460.

19 H. Naoi, F. Matsuda, T. Araki, A. Suzuki and Y. Nanishi, J. Cryst. Growth, 2004, 269, 155-161.

20 X. L. Zhu, L. W. Guo, N. S. Yu, J. F. Yan, M. Z. Peng, J. Zhang, H. Q. Jia, H. Chen and J. M. Zhou, J. Cryst. Growth, 2007, 306, 292-296.
21 S. Porntheeraphat and J. Nukeaw, Appl. Surf. Sci., 2008, 254, 7851-7854.

22 Q. Guo, K. Murata, M. Nishio and H. Ogawa, Appl. Surf. Sci., 2001, 169-170, 340-344.

23 M. Wintrebert-Fouquet, K. S. A. Butcher and P. P.-T. Chen, J. Cryst. Growth, 2004, 269, 134-138.

24 W. Jung, C. S. Ra and B. Min, Bull. Korean Chem. Soc., 2005, 26(9), 1354.

25 T. Zhang, A. Kouyama and T. Sugiura, J. Ceram. Soc. Jpn., 2012, 120(1397), 25-29.

26 G. Purwiandono, K. Manseki and T. Sugiura, J. Photochem. Photobiol., A, 2020, 394, 112499.

27 T. Lindgren, G. R. Torres, J. Ederth, R. Karmhag, C.-G. Granqvist and S.-E. Lindquist, Thin Solid Films, 2006, 50, 6-14.

28 E. R. Van Artsdalen and I. S. Yaffe, J. Phys. Chem., 1955, 59.2, 118-127.

29 Z. Chen, Y. Li, C. Cao, S. Zhao, S. Fathololoumi, Z. Mi and X. Xu, J. Am. Chem. Soc., 2012, 134(2), 780-783.

30 J. Kamimura, P. Bogdanoff, M. Ramsteiner, L. Geelhaar and H. Riechert, Semicond. Sci. Tech., 2016, 32, 074001.

31 X. D. Pu, J. Chen and W. Z. Shen, J. Appl. Phys., 2005, 98, 033527.

32 A. Miura, T. Takei and N. Kumada, Cryst. Growth Des., 2012, 12(9), 4545-4547.

33 M. T. Carter, M. E. Berton, K. L. Kies and J. L. Jeffers, Proc. Electrochem. Soc., 1999, PV 1999-41, 74-79. 